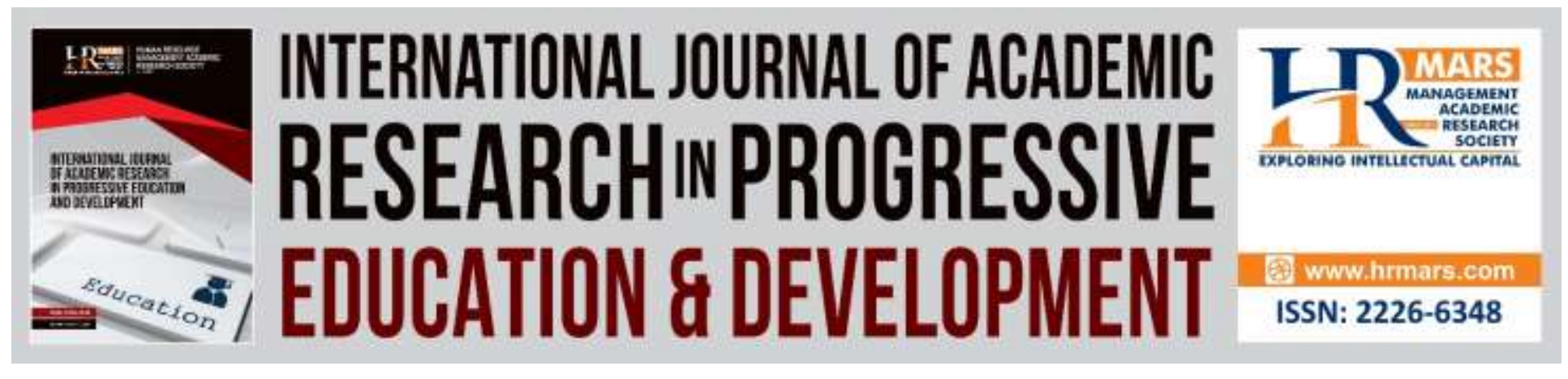

\title{
The Development of Higher Education for Sustainable Development Model (HESD): Critical Success Factors, Benefits, and Challenges
}

Mad Ithnin Salleh, Nurul Fadly Habidin, Khairunneezam Mohd Noor, Sharifah Zarina Syed Zakaria

To Link this Article: http://dx.doi.org/10.6007/IJARPED/v8-i4/6434

DOI: 10.6007/IJARPED/v8-i4/6434

Received: 13 July 2019, Revised: 11 August 2019, Accepted: 02 September 2019

Published Online: 23 September, 2019

In-Text Citation: (Salleh, Habidin, Noor, \& Zakaria, 2019)

To Cite this Article: Salleh, M. I., Habidin, N. F., Noor, K. M., \& Zakaria, S. Z. S. (2019). The Development of Higher Education for Sustainable Development Model (HESD): Critical Success Factors, Benefits, and Challenges. International Journal of Academic Research in Progressive Education and Development, 8(4), 47-54.

Copyright: (C) 2019 The Author(s)

Published by Human Resource Management Academic Research Society (www.hrmars.com)

This article is published under the Creative Commons Attribution (CC BY 4.0) license. Anyone may reproduce, distribute, translate and create derivative works of this article (for both commercial and non-commercial purposes), subject to full attribution to the original publication and authors. The full terms of this license may be seen

at: http://creativecommons.org/licences/by/4.0/legalcode

Vol. 8(4) 2019, Pg. 47- 54

http://hrmars.com/index.php/pages/detail/IJARPED

JOURNAL HOMEPAGE

Full Terms \& Conditions of access and use can be found at http://hrmars.com/index.php/pages/detail/publication-ethics 


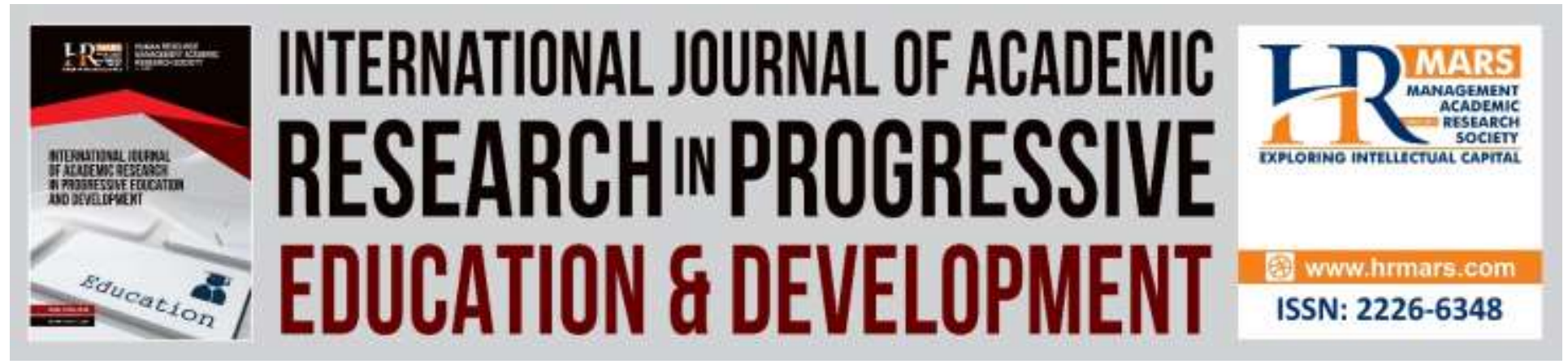

\title{
The Development of Higher Education for Sustainable Development Model (HESD): Critical Success Factors, Benefits, and Challenges
}

\author{
Mad Ithnin Salleh ${ }^{*}$, Nurul Fadly Habidin², Khairunneezam Mohd \\ Noor $^{3}$, Sharifah Zarina Syed Zakaria ${ }^{4}$ \\ ${ }^{* 1}, 2$ Faculty of Management and Economics, Universiti Pendidikan Sultan Idris, \\ 35900 Tanjung Malim, Perak, Malaysia, ${ }^{3}$ Faculty of Leadership and Management, Universiti \\ Sains Islam Malaysia, Bandar Baru Nilai, 71800 Nilai, Negeri Sembilan, Malaysia, ${ }^{4}$ Institute of \\ Environment and Development (LESTARI), Universiti Kebangsaan Malaysia, 43600 Bangi, \\ Selangor, Malaysia
}

\begin{abstract}
The Malaysian government has placed greater emphasis on the sustainable development of higher education institutions during the last decade. Higher education is beginning to include sustainable development concepts in their activities. Efforts in education for sustainable development are important to improve sustainability for Malaysian Public Higher Institutions. Therefore, it is important for every institution to identify the critical success factor for sustainable development as well as the benefit ad the challenges for higher education for sustainable development. This study aims to identify those elements and develop a measurement model of higher education for sustainable development for Malaysian Public Higher Institutions. To obtain the findings, a qualitative method will be used in this study. This study expected to provide better understanding and new insights for sustainable development in order to improve sustainability for Malaysian Public Higher Institutions.

Keywords: Higher Education for Sustainable Development, Sustainable Development, Higher Education Institution, Sustainability

\section{Introduction}

Higher institutions as a whole are structured to fulfill the research and teaching objectives. These objectives reinforce by the operational staff of the institutions (Davim \& Filho, 2016; Galdeano, Ahmed, Fati, Rehan, \& Ahmed, (2019) The common boundaries within the operational staff that devote gap between academic and general staff consistently create complexities for the institutions to develop creatively and retain their sustainability as higher institutions. Due to poor
\end{abstract}


sustainability consciousness, it leaves the institutions and its workforce unaware of the importance of understanding sustainability benefit and challenges.

Critical success factors are a limited number to ensure the success and performance of the organization mainly for Malaysian Public Higher Institutions. The critical factors that determine the successfulness of sustainability development first come with a certain level of knowledge from the stakeholder of every higher education institution. Knowledge is recognize as one of a key competency of sustainable development in institutions along with system thinking, emotions, ethics, value and action (Mochizuki \& Fadeeva, 2010). According to Awuzie \& Emuze (2018) the barriers to implement sustainable facilities management in university are identified as lack of knowledge, lack of capabilities, skills, time management and authority such as lack of guidance document about sustainable development. According to Minguet, MartinezAgut, Palacios, Piñero, \& UII, (2011); Ahmed, Majid, Zin, Phulpoto, \& Umrani, (2016) suggests introduce sustainability into university curriculum is a good basic start of sustainability-related approaches as the study reveal that education is one of the critical success factor. Other than that lack of training among educator also lead to insufficient sustainability benefit that can be offered to the student and student turnover may lead to the implication (Velazquez, Munguia, \& Sanchez, 2005). Apart from training, organizational structure also identified as one of the factor as with powerful organizational structure, the sustainable development will integrate successfully with education management (Figueiró \& Raufflet, 2015). Sustainability in environmental quality, social equity and economic validity can be achieved if the CSFs are properly addressed (Saleh, Mohammed, \& Abdullah, 2015).

The sustainability of higher education institutions is seen to benefit the long-term sustainability of the institutions. It provide the institutions with environmental sustainability, economics sustainability, institutional sustainability and integrated sustainability (Aleixo, Leal, \& Azeiteiro, 2016). Knowledge and understanding of environmental sustainability-related issue helps people becoming more aware and responsible towards the environment and sustainable project. Malaysian higher education had established collaboration with foreign university to build green technology to conserve environment and all the natural resource (Foo, 2013). Besides that, (Wu, Shen, \& Kuo, 2015) also finds that focus on zero disaster, reducing waste, protection on natural resources and improve energy efficiency is a right way to promote the concept of sustainability. Promotion of sustainable development has increase the interest in the quality and internationalization of research to increase education quality (Salvioni, Franzoni, \& Cassano, 2017). This proves that a higher education institution with appropriate sustainable development and support will receive a benefit in term of quality improvement for their respective institution.

Apart from benefits, higher education institution is facing challenges as they need a contribution to sustainability. According to Aleixo, Leal, \& Azeiteiro (2016), the challenges of sustainable development are lack of involvement, lack of funding in managing sustainable development, and lack of policy. The challenges for sustainable future do not only focus on the ability of the higher education institution to doing so, but for the willingness and the time frame for every higher education institution in adapting sustainable future. (Disterheft, Caeiro, 
Azeiteiro, \& Filho, 2015) reported that involvement and inspiration toward sustainability, the lack of time and availability as well as participatory approach or initiative are the potential causes of sustainability failures and successes in the university. While (Peter, Libunao, \& Latif, 2016) adding that it should be the involvement of an educator to build an initiative in using sustainability approach in research, teaching and learning activity in both formal and informal curricula. Other than that, government support and funding are also proven to increase the promotion of sustainability in academic development (Su \& Chang, 2010). According to Velazquez et al., (2005), lack of funding will diminished all effort in moving towards sustainable development for higher education. In Malaysia, considerable efforts had been applied by the government as an initiative to involve agendas of sustainable development in Malaysian higher education system. With sufficient in policy on sustainable development in higher education, the challenges in implementing sustainable development will be reduced and the beneficial advantage can be fruitful to the institution (Down \& Down, 2006).

Therefore, there is a gap in sustainable development implementation in higher education. This research focused on three challenges which is lack of involvement, lack of funding, and lack of policy. This is because three challenges for sustainable development can be determined in order to improve the performance of higher education, particularly in Malaysian Public Higher Institutions. This research is important for helping institutions to improve higher education sustainable development in Malaysian Public Higher Institutions. Therefore, this research is focused on benefits for sustainable development such as environmental sustainability, integrated sustainability, and institutional sustainability, promote sustainability, and quality improvement in order to address sustainability issues in higher education.

\section{Objective of the Study}

This research aim to achieve the objective of:

1. To identify CSFs for higher education sustainable development in Malaysian Public Higher Institutions.

2. To identify benefits for higher education sustainable development in Malaysian Public Higher Institutions.

3. To identify challenges for higher education sustainable development in Malaysian Public Higher Institutions.

4. To develop the propose model for higher education sustainable development in Malaysian Public Higher Institutions.

\section{Method}

This study is a quantitative study where data collected are using purposive sampling method. Respondents are consisting of lecturer and professional staff working in academic department. The research location is public university which universities are listed in the university which committed to Higher Education and Research for Sustainable Development as stated by International Association of University (IAU). The data were analyzed using descriptive analysis 
and structural equation modeling. The tools for analyzing the statistical data are Statistical Package for Social Science (SPSS) version 20 software and AMOS software respectively. The reliability analysis for the descriptive statistic is analyzed using Chronbach's Alpha and exploratory factor analysis to determine the reliability and validity of each construct. The measurement construct are using Likert's Scale from 1 (Strongly disagree) to 5 (Strongly agree) which consist of the critical success factor, benefit and challenges of higher education for sustainable development. The measurement represents the existing condition, experience and expectation of the respondent to their respective institution.

\section{Findings}

Profile of respondent

Questionnaires were distributed to 405 respondents from five different public university registered as a member of International Associates of University (IAU) that committed to Higher Education and Research for Sustainable Development. Majority of the respondents are female $(67.7 \%)$, bachelor degree holder (42.2\%), working as a lecturer $(64.2 \%)$, permanent employee (65.7\%), and have worked for 1 to 5 years in their respective institution (48.1\%).

Preliminary Analysis

Normality, outliers and multicollinearity of SEM assumptions were checked. There are 49 extreme cases identified as outliers and were removed from the sample and the measurement model is ready for validation.

\section{Validation of the Measurement Model}

The assessment of reliability and validity shows construct reliability (CR), average variance extracted (AVE) factor loadings, square root of the AVE and inter-construct correlations (IC) indicate the model were fit, reliable and validate to test for the proposed hypotheses.

\section{Descriptive Analysis}

The critical success factor identified in this study are knowledge, education, awareness, training and organizational structure. While for benefit identified is environmental sustainability, integrated sustainability, promote sustainability, institutional sustainability and quality improvement. For the challenges, this study identified lack of involvement, lack of funding as well as lack of policy as the challenges in higher education for sustainable development in Malaysian Public Higher Institution.

\section{Hypotheses Testing: Direct Effect}

Finally, the propose model for higher education sustainable development in Malaysian Public Higher Institutions as per below: 


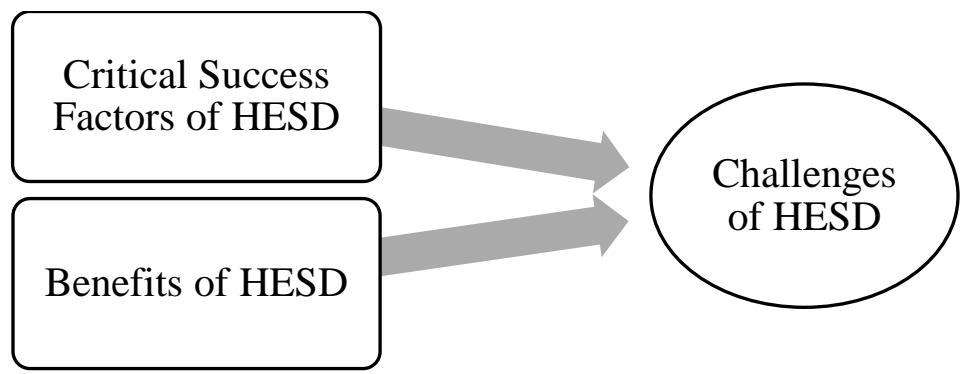

Figure 1.0. The framework for Higher Education for Sustainable Development in Malaysian Public Higher Institution

According to the result of reliability, validity and model fit, the model is appropriate to be hypothesized using SEM by AMOS. Particularly, the result shows $\mathrm{R}^{2}$ value of 0.843 , indicating that 84.3 percent of the variance in challenges of HESD can be explained by benefit and critical success factor. The effect of benefit on challenges is positive and significant $(\beta=0.729, p<0.001)$. Along with the effect of critical success factor on challenges also positive and significant $(\beta=0.21$, $p<0.005)$. Thus the hypotheses are supported.

\section{Conclusion}

As a conclusion, Malaysian Public Higher Institution needs to highlight the critical success factor to experience the benefit of having sustainable education institution. Apart from that, the institutions also need to overcome the challenges by mastering the success factor and proving the benefit to the higher level of management. Additionally, this study provides insights to guide future efforts to join educational efforts with practical and local concerns about sustainability development and to provide additional benefits for Malaysian Public Higher Institutions. Thus, the model of higher education for sustainable development for Malaysian Public Higher Institutions developed should be implemented by every higher institution in Malaysia. The model can further assist the Malaysian Public Higher Institutions to improve the sustainability in higher education. Furthermore, it can address sustainability issues and consider this as a criterion to improve sustainable development, mainly for the society. By implementing sustainable development, this research promotes sustainability and knowledge for enhancing learning for Malaysian Public Higher Institutions. This research is to continually improve their practices and sustainable improvement to become more systematic, efficient, and effective. This research can be used for sustainable education in terms of work process, procedures, and evaluation to achieve a certain level of performance improvement in order to enhance better performance and good support for managing the environment for Malaysian Public Higher Institutions.

\section{Acknowledgement}

This research was funded by Regional Cluster For Research and Publication (RCRP) 2017-0048106-61, joint venture between Universiti Pendidikan Sultan Idris (UPSI) and Universiti Kebangsaan Malaysia (UKM). 
INTERNATIONAL JOURNAL OF ACADEMIC RESEARCH IN PROGRESSIVE EDUCATION AND DEVELOPMENT

Vol. 8, No. 4, 2019, E-ISSN: 2226-6348 ㄷ 2019 HRMARS

\section{Corresponding Author}

Nurul Fadly Habidin

Faculty of Management and Economics, Universiti Pendidikan Sultan Idris, 35900 Tanjung Malim, Perak, Malaysia

Email: fadly@fpe.upsi.edu.my

\section{References}

Ahmed, U., Majid, A. H., Zin, M. L., Phulpoto, W., \& Umrani, W. A. (2016). Role and impact of reward and accountability on training transfer. Business and Economics Journal, $7(1)$. http://dx.doi.org/10.4172/2151-6219.1000195

Aleixo, A. M., Leal, S., \& Azeiteiro, U. M. (2016). Conceptualization of sustainable higher education institutions, roles, barriers, and challenges for sustainability: An exploratory study in Portugal. Journal of Cleaner Production, 1-10. https://doi.org/10.1016/j.jclepro.2016.11.010

Awuzie, B. O., Emuze, F., \& Ngowi, A. (2018). Critical Success Factor for Smart and Sustainable Facilities Management in a Sount Africa University of Technology (pp. 1-8). Retrieved from https://www.researchgate.net/publication/324835054\%0ACRITICAL

Davim, J. P., \& Filho, W. L. (2016). Challenges in Higher Education for Sustainability. London: Springer International Publishing Switzerland. https://doi.org/10.1007/978-3-319-23705-3

Disterheft, A., Caeiro, S., Azeiteiro, U. M., \& Filho, W. L. (2015). Sustainable universities - A study of critical success factors for participatory approaches. Journal of Cleaner Production, 106, 11-21. https://doi.org/10.1016/j.jclepro.2014.01.030

Down, L., \& Down, L. (2006). Addressing the challenges of mainstreaming education for sustainable development in higher education. https://doi.org/10.1108/14676370610702190

Figueiró, P. S., \& Raufflet, E. (2015). Sustainability in higher education: A systematic review with focus on management education. Journal of Cleaner Production, 106, 22-33. https://doi.org/10.1016/j.jclepro.2015.04.118

Foo, K. Y. (2013). A vision on the role of environmental higher education contributing to the sustainable development in Malaysia. Journal of Cleaner Production. https://doi.org/10.1016/j.jclepro.2013.05.014

Galdeano, D., Ahmed, U., Fati, M., Rehan, R., \& Ahmed, A. (2019). Financial performance and corporate social responsibility in the banking sector of Bahrain: Can engagement moderate? Management Science Letters, 9(10), 1529-1542.

Minguet, P. A., Martinez-Agut, M. P., Palacios, B., Piñero, A., \& UII, M. A. (2011). Introducing sustainability into university curricula: $A n$ indicator and baseline survey of the views of university teachers at the University of Valencia. Environmental Education Research, 17(2), 145-166. https://doi.org/10.1080/13504622.2010.502590

Mochizuki, Y., \& Fadeeva, Z. (2010). Competences for sustainable development and sustainability: Significance and challenges for ESD. International Journal of Sustainability in Higher Education, 11(4), 391-403. https://doi.org/10.1108/14676371011077603

Peter, C. J., Libunao, W. ., \& Latif, A. (2016). Extent Of Education For Sustainable Development 
(ESD) Integration In Malaysian Community Colleges. Journal of Technical Education and Training (JTET), 8(1), 1-13.

Saleh, A. A., Mohammed, A. H., \& Abdullah, M. N. (2015). Critical Success Factors for Sustainable University: A Framework from the Energy Management View. Procedia - Social and Behavioral Sciences, 172, 503-510. https://doi.org/10.1016/j.sbspro.2015.01.392

Salvioni, D. M., Franzoni, S., \& Cassano, R. (2017). Sustainability in the higher education system: An opportunity to improve quality and image. Sustainability (Switzerland), 9(6), 1-27. https://doi.org/10.3390/su9060914

Su, H. J., \& Chang, T. chau. (2010). Sustainability of higher education institutions in Taiwan. International Journal of Sustainability in Higher Education, 11(2), 163-172. https://doi.org/10.1108/14676371011031883

Velazquez, L., Munguia, N., \& Sanchez, M. (2005). Deterring sustainability in higher education institutions: An appraisal of the factors which influence sustainability in higher education institutions. International Journal of Sustainability in Higher Education, 6(4), 383-391. https://doi.org/10.1108/14676370510623865

Wu, Y. C. J., Shen, J. P., \& Kuo, T. (2015). An overview of management education for sustainability in asia. International Journal of Sustainability in Higher Education, 16(3), 341-353. https://doi.org/10.1108/IJSHE-10-2013-0136 